\title{
Tuberculosis and comorbidities in urban areas in Argentina. A gender and age perspective
}

\author{
Alberto Echazarreta $(\dagger)^{1}$, Elsa Zerbini ${ }^{2}$, José De Sandro ${ }^{3}$, César Sáenz ${ }^{4}$, Leila Yessi ${ }^{5}$, \\ Romina Saad ${ }^{6}$, Gabriela Manonelles ${ }^{7}$, Mónica Cuello ${ }^{8}$

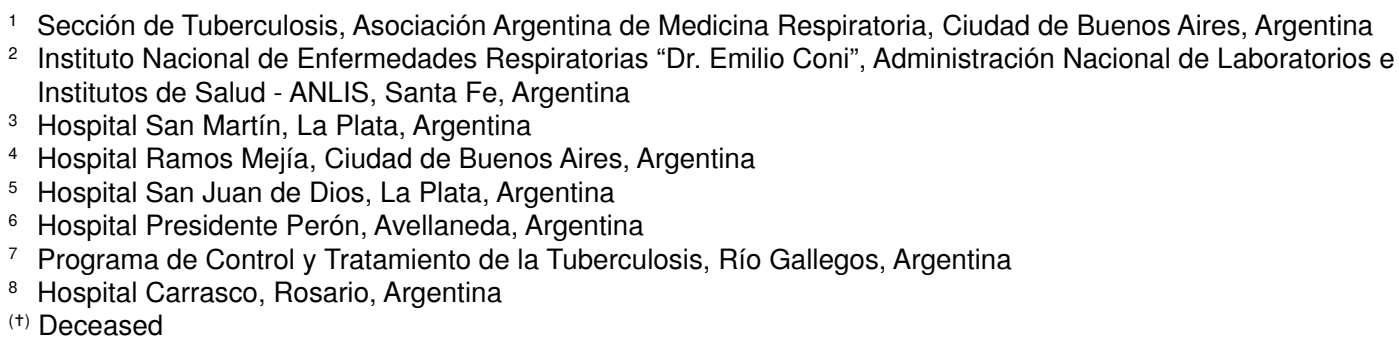

Introduction: Tuberculosis continues to be a major health problem in the world with an incidence of more than 10 million cases in 2015. There are factors that change the risk of developing the disease after infection, as well as the presentation of the disease.

Objective: To determine the main comorbidities and demographic, clinical and microbiological characteristics of tuberculosis adult patients in Argentina from a gender and age perspective.

Materials and methods: We conducted a cross-sectional study in urban referral hospitals for patients with tuberculosis. We included tuberculosis patients of 15 years or more of age who were hospitalized or treated in outpatient clinics with bacteriologically confirmed pulmonary or extrapulmonary forms of the disease, as well as those who, although not bacteriologically confirmed, had clinical and radiological characteristics consistent with tuberculosis. The study period was from August $1^{\text {st }}, 2015$ to August $31^{\text {st }}, 2016$.

Results: We included 378 patients. The median age was 37 years. Male gender was associated with extrapulmonary tuberculosis, hospitalization, smoking, drug addiction and alcoholism. Tuberculosis and aids (22.6\%) was related to drug use, admission into hospital, extrapulmonary tuberculosis, nonaddiction to tobacco, non-pathological radiology, absence of cavitation, and negative sputum smear microscopy. Patients less than 40 years of age had a higher rate of drug addiction and low weight, while those aged 40 or over had a higher proportion of diabetes, alcoholism and chronic obstructive pulmonary disease (COPD).

Conclusions: This study will help recognize tuberculosis patients' characteristics and comorbidities influencing the development and evolution of the disease from an age and gender perspective to enable the development of social and community-based strategies.

Key words: Tuberculosis; comorbidity; gender identity; age groups; acquired immunodeficiency syndrome; risk factors; Argentina.

doi: https://doi.org/10.7705/biomedica.v38i0.3904

Tuberculosis y comorbilidades en áreas urbanas de Argentina. Una perspectiva de edad y sexo

Introducción. La tuberculosis continúa siendo un importante problema de salud en el mundo, con una incidencia de más de 10 millones de casos en el 2015. Hay factores que modifican el riesgo de desarrollar la enfermedad luego de contraer la infección, así como su forma de presentación.

Objetivo. Determinar las principales comorbilidades y características demográficas, clínicas y microbiológicas de pacientes adultos con tuberculosis en Argentina, mediante un análisis desde la perspectiva de sexo y edad.

Materiales y métodos. Se llevó a cabo un estudio transversal en hospitales de referencia para pacientes de áreas urbanas con tuberculosis. Se incluyeron pacientes de 15 años o más con

\footnotetext{
Author's contributions:

Alberto Echazarreta: design of the study protocol

Elsa Zerbini: design of the study protocol, analysis of the information and writing of the final report

José De Sandro: review of the study protocol,coordination of field work, data collection and review of the final report

César Saenz, Leila Yessi, RominaSaad, Gabriela Manonelles and Mónica Cuello: review of the study protocol, data collection and review of the final report
} 
tuberculosis pulmonar o extrapulmonar, confirmada bacteriológicamente y en tratamiento hospitalario o ambulatorio, y también, pacientes sin confirmación bacteriológica, pero con características clínicas y radiológicas indicativas de tuberculosis. El período de estudio fue del 1ํo de agosto de 2015 al 31 de agosto de 2016.

Resultados. Se incluyeron 378 pacientes. La mediana de edad fue de 37 años. El sexo masculino estuvo asociado con tuberculosis extrapulmonar, hospitalización, tabaquismo, adicción a drogas y alcoholismo. Los menores de 40 años presentaron adicción a drogas y bajo peso con mayor frecuencia, en tanto que los de 40 años o más presentaron, en mayor proporción, diabetes, alcoholismo y enfermedad pulmonar obstructiva crónica (EPOC). Se observaron más casos de sida en el sexo masculino, y en edades de 40 años y más.

Conclusiones. Este trabajo permitió conocer las características y las comorbilidades de enfermos de tuberculosis, que influyen en el desarrollo y la evolución de la enfermedad, desde una perspectiva de edad y sexo, con el objetivo de facilitar enfoques de manejo que incorporan aspectos sociales y comunitarios.

Palabras clave: tuberculosis; comorbilidad; identidad de género; grupos de edad; síndrome de inmunodeficiencia adquirida; factores de riesgo; Argentina.

doi: https://doi.org/10.7705/biomedica.v38i0.3904

In 2015, an estimate of 10.4 million tuberculosis (TB) incident cases occurred on a global scale, 142 per 100,000 inhabitants; $62 \%$ were male, $90 \%$ were adult and $11 \%$ were HIV-positive. In the National TB Programs (NTP, 6.1 million new TB cases were reported, with the extrapulmonary form accounting for $15 \% ; 57 \%$ of pulmonary TB (PTB) new and relapse cases were bacteriologically confirmed (1).

In Argentina, 10,713 TB cases were reported to the NTP in 2015 (24.8 per 100,000 inhabitants); new cases and relapses accounted for $91.1 \%$, the highest notification rate being observed between 20 and 24 -year-old patients, with $85.5 \%$ of pulmonary localization, $70.0 \%$ with bacteriological confirmation, sputum smear microscopy, SSM, or culture and $63.8 \%$ with positive SSM (SSM +). Among extrapulmonary localizations, the pleural was the most frequent, followed by the lymph node and meningeal localizations. Coverage of HIV testing in patients with TB was $19.8 \%$, of whom $33.4 \%$ were positive; positivity dropped to $6.5 \%$ when the total number of cases was considered (2).

The risk of developing TB after contracting infection is variable. Some risk factors are known to facilitate the development of the disease and to provoke a greater or lesser degree of immunodeficiency, increasing up to 1,000 times the odds of suffering from TB as opposed to people without such risk factors (3).

\footnotetext{
Corresponding author:

Elsa Zerbini, Instituto Nacional de Enfermedades Respiratorias "Dr. Emilio Coni", Administración Nacional de Laboratorios e Institutos de Salud - ANLIS, Santa Fe, Argentina

Telephone and fax: (54-0342) 489 2827/6851; int. 107

elsazerbini@arnet.com.ar
}

Received: 07/06/17; accepted: 28/08/17
Common immunocompromised conditions include HIV/AIDS, advanced age, cancer, immunosuppressive therapies, diabetes mellitus, renal diseases requiring dialysis, malnutrition and liver cirrhosis (4).

HIV infection has been the most important risk factor for developing TB in countries with a high burden of the disease. However, epidemiological studies have highlighted the relevance of other factors in perpetuating epidemic TB, including smoking and diabetes mellitus (5).

Risk factors may also change PTB presentation, including age, diabetes mellitus, AIDS, chronic kidney disease, and malnutrition. Some authors found that age can influence clinical symptoms and radiographic manifestations, with less cavitation frequency in very advanced age or very young groups. Conversely, diabetes mellitus is associated with higher odds of having cavities (6).

The aforementioned risk factors, along with pregnancy and breastfeeding, also impact on treatment. Although standard treatment regimens are used, close patient follow-ups should be performed and each case individually assessed (3). In patients with comorbidities and other conditions, such as HIV and smoking, a higher percentage of TB recurrence has been reported $(7,8)$. In Istanbul, Turkey, the presence of alcoholism and smoking, old age, low weight and SSM positivity, was associated with male gender (9). Other authors reported an association between addiction and gender (10-12).

A study conducted in a Buenos Aires city hospital in Argentina between 1997 and 2010 determined that the most frequent TB comorbidities and other conditions were smoking (14\%); HIV (6.5\%); asthma (5.6\%) and alcoholism (4.8\%) (13). Another 
study conducted with TB patients over 15 years old in Córdoba city, Argentina, reported low weight $(63 \%)$, smoking $(61 \%)$, alcoholism $(23 \%)$, illicit drugs (22\%) and diabetes mellitus (19\%), as major comorbidities (14).

Eighty percent of the Latin American and Caribbean population lives in cities, a proportion that grew twofold between 1950 and 2010. The burden of TB is higher in urban than in rural areas, both in developed and developing countries, this being largely attributed to living conditions of the population living in peripheral slums (15).

In order to control TB, comprehensive health care with an inter-programmatic and cross-sector approach is required, coordinating different actors and sectors, addressing the main health determinants which promote and aggravate the TB endemic, especially in marginal slum populations from large cities. This study aimed to determine the main comorbidities, associated conditions and demographic, clinical and microbiological characteristics of adult TB patients from urban centers in Argentina from a gender and age perspective.

\section{Materials and methods}

We conducted a cross-sectional study in referral hospitals for TB patients from urban areas with more than 90,000 inhabitants located in the provinces of Buenos Aires, Santa Fe, Santa Cruz and the Autonomous City of Buenos Aires. Three provinces are in the central region of the country and they have a temperate climate and four well-defined seasons; the two cities in Santa Cruz province belong to the semi-desert region of Patagonia, where the climate is cold, dry, and continuously drafty. The cities or municipalities where the study hospitals are located were selected for convenience: Caleta Olivia and Río Gallegos (Santa Cruz), Avellaneda, Florencio Varela, Lanús, Lomas de Zamora, La Plata, Merlo, Quilmes, and San Fernando (Buenos Aires), Rosario (Santa Fe), and Buenos Aires city. We included TB patients of $\geq 15$ years of age who were hospitalized or treated by outpatient clinics with bacteriologically confirmed pulmonary or extrapulmonary TB, as well as patients who, although not bacteriologically confirmed, had clinical and radiological characteristics consistent with TB and were prescribed TB treatment.

The study period was from August $1^{\text {st }}, 2015$, to August $31^{\text {st }}, 2016$. Information was obtained from patients' medical records and/or treatment cards. A form was specifically designed for the study observing enough caution to keep confidentiality and not to reveal identities. In the event that by error or omission this information was not available or not clear enough, an interview was conducted with the patients and/or their companions, where their consent was requested. Patients whose information records could not be completed or clarified were excluded. The study was authorized by hospital officers and approved by the ethics committee within each of them.

Variables in the study included: gender, age, place of residence, nationality (based on the birthplace), years of residence in Argentina, height and weight, TB type (pulmonary or extrapulmonary), type of extrapulmonary TB, type of comorbidity or condition at the time of diagnosis, pregnancy or puerperium, history of previous TB treatment; SSM results, culture and chest X-ray at the time of diagnosis; HIV serology and treatment results, and need of hospitalization during treatment.

Two types of patients were considered: New and with a history of treatment. New patients were considered as those who had never had TB treatment, or else were treated for TB for less than a month; patients with a history of treatment were those who were previously treated for TB for more than one month and diagnosed again as having active TB.

Anyone who smoked at least 100 cigarettes in his life and smoked some days or every day at the time was considered a smoker.

For the calculation of the body mass index (BMI), weight and height were measured at the beginning of treatment.

The World Health Organization (WHO) definition of alcoholism was adopted: daily ingestion of alcohol in excess of $50 \mathrm{~g}$ in women and $70 \mathrm{~g}$ in men. This condition was recorded when this daily alcohol consumption was determined by the interview. To define drug addiction, we considered those substances that patients declared in the interview as having used in a compulsive fashion.

\section{Data analysis}

Data analysis was performed using Epilnfo software 7.1.5.2. For continuous variables, the mean, median and range were determined. To evaluate the association between TB patients' comorbidities or characteristics and gender, the presence of aids and age groups, we performed a univariate analysis; for categorical variables, we used the 
chi square test or the Fischer exact test. When $p$ was less than 0.050 , the result was considered statistically significant.

Variables with information from more than 300 TB cases that resulted in a significance of $p<0.100$ in the univariate analysis were included in a multivariate logistic regression model. The strength of the association was determined with odds ratios (OR) and their $95 \%$ confidence intervals $(\mathrm{Cl})$. When $p$ was less than 0.050 , the result was considered statistically significant.

\section{Results}

We included 378 patients: 163 (43.1\%) from Buenos Aires province, 120 (31.7\%) from Buenos Aires city, 49 (13.0\%) from Rosario city, Santa Fe province, and 46 (12.2\%) from Santa Cruz province. The mean age was 39.7 and the median age 37 (range: 15-89 years). Sixty-five percent of TB patients were between 15 and 45 years and the highest frequency (36.4\%) was registered in the 15 to 30 year group. Fifty-eight percent $(58.2 \%)$ of TB patients were male; the male/female ratio was 1.34 in new patients and relapses, and 2.27 in those with a history of treatment.

Among the 327 patients who had the SSM result, the culture result of 216 was known, with 139/216 SSM (+) having positive culture. Only $1 / 140$ patients with positive SSM resulted in a negative culture. None of the patients in the study was diagnosed by molecular methods.

The characteristics and comorbidities of patients by gender are shown in table 1. Those showing a statistically significant association with male gender were: extrapulmonary TB (including mixed: pulmonary and extrapulmonary TB), hospitalization, smoking, drug addiction, and alcoholism, with the following proportions of 37.0, 31.8, 31.5, 20.5 and $15.1 \%$, respectively, in men. Using a multivariate analysis, alcoholism (OR=2.89; $95 \% \mathrm{Cl}$ : 1.01 8.21; $p=0.047)$ and extrapulmonary TB $(O R=2.94$; $95 \% \mathrm{Cl}: 1.64-5.26 ; p=0.000$ ) were confirmed as statistically significant.

Of the 42 patients with information on the type of drug they used, $71.4 \%$ used more than one type, the most frequent combination being marijuana and cocaine.

The BMI mean was 21.6 and the median, 21.2 (range: $13.1-38.3$ ). Of 206 TB patients, $24.3 \%$ were underweight $(\mathrm{BMI}<18.5), 14.6 \%$ were overweight (BMI: 25-29.99) and 5.3\% were obese $(B M I \geq 30)$.
Overweight or obese patients had a higher proportion of diabetes mellitus (OR=10.96; $95 \% \mathrm{Cl}$ : $4.60-26.12 ; p=0.000$ ).

Other comorbidities with a frequency higher than $2 \%$ were: COPD $(2.9 \%)$, rheumatic disease $(2.9 \%)$, hypertension (2.6\%), immunosuppressive treatment $(2.6 \%)$, renal disease (2.4\%), and cancer $(2.1 \%)$.

There were three pregnant patients and one puerpera, accounting for $0.8 \%$ and $0.3 \%$ of total cases, respectively.

Information on the presence or absence of multidrug resistance was obtained for 150 patients and four $(2.7 \%)$ were multiresistant. Of 155 patients from whom monoresistance information was collected, eight $(5.2 \%)$ were resistant to isoniazid and six $(3.9 \%)$ to rifampicin.

Out of 376 TB patients 85 (22.6\%) had AIDS. A statistically significant association was observed between the presence of AIDS and drug use $(p=0.000)$, need for hospitalization $(p=0.000)$, extrapulmonary TB $(p=0.002)$, extrapulmonary TB in localizations other than pleural $(p=0.001)$, non-pathological radiology $(p=0.001)$, cavitation absence $(p=0.001)$, and negative SSM $(p=0.000)$ (table 2). The main forms of extrapulmonary TB were miliary, meningeal, and lymph node TB. Using multivariate analysis in relation to presence of AIDS, drug use (OR: 3.45 (1.04-11.41); p: 0.042), hospitalization (OR=4.70; $95 \% \mathrm{Cl}$ : 2.03-10.87; $p=0.000)$, non-pathological radiology $(O R=11.11$; $95 \% \mathrm{Cl}: 1.49-100.00 ; p=0.020)$ and SSM (-) (OR= 10 ; $95 \% \mathrm{Cl}: 4-25 ; p=0.000)$ were confirmed as statistically significant.

Of 25 HIV-infected patients whose CD4 T-lymphocyte counts were known, 22 had counts below 200 cells $/ \mathrm{mm}^{3}$.

On the basis of the median age of TB patients, the population was divided into two groups: $<40$ years and $\geq 40$ years. A statistically significant association was observed between those $<40$ years and drug addiction $(p=0.015)$ and low weight $(p=0.004)$ (table 3). Patients $\geq 40$ years of age showed a statistically significant association with the presence of diabetes mellitus $(p=0.000)$, alcoholism $(p=0.010)$ and COPD presence $(p=0.027)$. Using multivariate analysis, an association was confirmed between TB patients $<40$ and drug addiction $(\mathrm{OR}=2.71$; 95\% Cl: 1.34-5.49; $p=0.042)$, and between those $>40$ and alcoholism (OR=3.45; $95 \% \mathrm{Cl}$ : 1.54-7.69; $\mathrm{p}=0.002)$, and diabetes mellitus $(\mathrm{OR}=4.35 ; 95 \% \mathrm{Cl}$ : $2.08-9.09 ; p=0.000$ ). 
Table 1. Comorbidities, other associated conditions and demographic, clinical, and microbiological characteristics of tuberculosis adult patients in urban conglomerates of Argentina, according to gender. August 2015-August 2016

\begin{tabular}{|c|c|c|c|c|c|c|}
\hline Characteristic & & Total $^{1}$ & Male & Female & OR $^{2}$ & $p^{3}$ \\
\hline \multicolumn{7}{|l|}{ Argentinian ${ }^{4}$} \\
\hline & Yes & $284(79.8)$ & $162(77.9)$ & $122(82.4)$ & $0.75(0.44-1.28)$ & 0.293 \\
\hline & No & 72 (20.2) & $46(22.1) 208$ & $26(17.6)$ & & \\
\hline & Total & $356(100.0)$ & $(100.0)$ & $148(100.0)$ & & \\
\hline \multicolumn{7}{|l|}{ Hospitalized $^{5}$} \\
\hline & Yes & $84(26.3)$ & 57 (31.8) & $27(19.3)$ & $1.95(1.16-3.30)$ & 0.012 \\
\hline & No & 235 (73.7) & $122(68.2)$ & $113(80.7)$ & & \\
\hline & Total & $319(100.0)$ & $179(100.0)$ & $140(100.0)$ & & \\
\hline \multicolumn{7}{|l|}{ Low weight } \\
\hline & Yes & $49(23.9)$ & $27(23.7)$ & $22(24.2)$ & $0.97(0.51-1.86)$ & 0.935 \\
\hline & No & $156(76.1)$ & 87 (76.3) & $69(75.8)$ & & \\
\hline & Total & $205(100.0)$ & $114(100.0)$ & $91(100.0)$ & & \\
\hline \multicolumn{7}{|l|}{ New case } \\
\hline & Yes & $318(86.4)$ & $180(83.7)$ & $138(90.2)$ & $0.56(0.29-1.06)$ & 0.074 \\
\hline & No & $50(13.6)$ & 35 (16.3) & $15(9.8)$ & & \\
\hline & Total & $368(100.0)$ & $215(100.0)$ & $153(100.0)$ & & \\
\hline \multicolumn{7}{|c|}{ Extrapulmonary ${ }^{6} \mathrm{~TB}^{7}$} \\
\hline & Yes & $109(29.3)$ & $80(37.0)$ & $29(18.6)$ & $2.58(1.58-4.20)$ & 0.000 \\
\hline & No & $263(70.7)$ & $136(63.0)$ & $127(81.4)$ & & \\
\hline & Total & $372(100.0)$ & $216(100.0)$ & $156(100.0)$ & & \\
\hline \multicolumn{7}{|l|}{ Cavitation } \\
\hline & Yes & $133(51.0)$ & $72(50.3)$ & $61(51.7)$ & $0.95(0.58-1.54)$ & 0.829 \\
\hline & No & $128(49.0)$ & 71 (49.7) & 57 (48.3) & & \\
\hline & Total & $261(100.0)$ & $143(100.0)$ & $118(100.0)$ & & \\
\hline \multicolumn{7}{|l|}{$\operatorname{SSM}(+)^{8}$} \\
\hline & Yes & $210(64.2)$ & $114(60.6)$ & $96(69.1)$ & $0.70(0.44-1.11)$ & 0.128 \\
\hline & No & $117(35.8)$ & 74 (39.4) & $43(30.9)$ & & \\
\hline & Total & $327(100.0)$ & $188(100.0)$ & $139(100.0)$ & & \\
\hline \multicolumn{7}{|l|}{ AIDS } \\
\hline & Yes & $85(22.6)$ & $57(26.0)$ & $28(17.8)$ & $1.62(0.97-2.69)$ & 0.061 \\
\hline & No & 291 (77.4) & $162(74.0)$ & $129(82.2)$ & & \\
\hline & Total & $376(100.0)$ & $219(100.0)$ & $157(100.0)$ & & \\
\hline \multicolumn{7}{|l|}{ Diabetes } \\
\hline & Yes & $47(12.5)$ & $31(14.2)$ & $16(10.2)$ & $1.45(0.76-2.76)$ & 0.252 \\
\hline & No & $329(87.5)$ & $188(85.8)$ & $141(89.8)$ & & \\
\hline & Total & $376(100.0)$ & $219(100.0)$ & $157(100.0)$ & & \\
\hline \multicolumn{7}{|l|}{ Alcoholism } \\
\hline & Yes & $39(10.4)$ & $33(15.1)$ & $6(3.8)$ & $4.46(1.82-10.94)$ & 0.000 \\
\hline & No & 337 (89.6) & $124(84.9)$ & $213(96.2)$ & & \\
\hline & Total & $376(100.0)$ & $157(100.0)$ & $219(100.0)$ & & \\
\hline \multicolumn{7}{|l|}{ Drug addiction } \\
\hline & Yes & $55(14.6)$ & 45 (20.5) & $10(6.4)$ & $3.80(1.85-7.81)$ & 0.000 \\
\hline & No & $321(85.4)$ & $174(79.5)$ & $147(93.6)$ & & \\
\hline & Total & $376(100.0)$ & $219(100.0)$ & $157(100.0)$ & & \\
\hline \multicolumn{7}{|l|}{ Smoking } \\
\hline & Yes & $101(26.9)$ & $69(31.5)$ & $32(20.4)$ & $1.80(1.11-2.91)$ & 0.016 \\
\hline & No & 275 (73.1) & $150(68.5)$ & $125(79.6)$ & & \\
\hline & Total & $376(100.0)$ & $219(100.0)$ & $157(100.0)$ & & \\
\hline
\end{tabular}

${ }^{1}$ Values expressed as $\mathrm{n}(\%) ;{ }^{2} \mathrm{OR}$ : Odds ratio; ${ }^{3} \mathrm{p}$ : $\mathrm{p}$ value; ${ }^{4}$ Argentinian: born in Argentina; ${ }^{5} \mathrm{Hospitalized:} \mathrm{patient} \mathrm{who} \mathrm{required} \mathrm{hospitalization} \mathrm{during}$ treatment; ${ }^{6}$ Extrapulmonary TB: includes exclusive extrapulmonary locations and mixed locations (pulmonary + extrapulmonary); ${ }^{7}$ TB: tuberculosis;

${ }^{8} \mathrm{SSM}(+)$ : positive sputum smear microscopy

\section{Discussion}

Identification of the best strategies for prevention and control of coexisting diseases is vital for progress towards the fulfillment of the Sustainable Development and the End TB Strategy Goals. This can only be possible with a thorough knowledge of how these diseases develop. Although social determinants of health are the chief factors behind the ongoing TB pandemic, there are other known risk factors of Mycobacterium tuberculosis infection and progression to active disease (16). This study aimed at determining the main comorbidities and conditions, and demographic, clinical, and 
bacteriological characteristics of adult TB patients in urban centers in Argentina, approaching them from a gender and age perspective.

The highest frequency of ages in the 15-to-30 year group coincides with the information published by Argentina's NTP, where the highest new case and relapse notification rates occur in groups of 20 to 24 , 25 to 29 and 30 to 34 years (2). The prevalence of new cases and relapses in young groups could be attributed to a TB sustained transmission in the community. In keeping with reports from the Argentinean NTP, there is a higher proportion of males, both in new and relapsed cases and in non-new ones (2).
WHO indicates that active or passive exposure to tobacco smoke is significantly associated with both TB infection and disease. Being an active smoker is also significantly associated with recurrent TB and mortality by TB (17).

Hassmiller, in a review, concludes that smoking is associated with risks of becoming infected with $M$. tuberculosis, developing TB, presenting with TB more severe forms, and dying from it, observing in many cases a strong dose-response relationship, in terms of smoking volume as well as duration (18). In this study, smoking appears as the most frequent condition among TB patients.

Table 2. Comorbidities, other associated conditions and demographic, clinical, and microbiological characteristics of tuberculosis adult patients in urban conglomerates of Argentina, according to their AIDS status. August, 2015-August, 2016

\begin{tabular}{|c|c|c|c|c|c|}
\hline Characteristic & Total $^{1}$ & With AIDS & Without AIDS & OR $^{2}$ & $\mathbf{p}^{3}$ \\
\hline \multicolumn{6}{|l|}{$<40$ years } \\
\hline Yes & $202(54.0)$ & $40(47.1)$ & $162(56.1)$ & $0.70(0.43-1.13)$ & 0.144 \\
\hline No & $172(46.0)$ & 45 (52.9) & 127 (43.9) & & \\
\hline Total & $374(100.0)$ & $85(100.0)$ & $289(100.0)$ & & \\
\hline \multicolumn{6}{|l|}{ Drug addiction } \\
\hline - & $55(14,8)$ & $29(33.7)$ & $26(9.2)$ & $4.99(2.75-9.07)$ & 0.000 \\
\hline No & 321 (85.2) & 57 (66.3) & $264(90.8)$ & & \\
\hline Total & $376(100.0)$ & $86(100.0)$ & $290(100.0)$ & & \\
\hline \multicolumn{6}{|l|}{ Alcoholism } \\
\hline Yes & $40(10.6)$ & $14(16.3)$ & $26(8.9)$ & $1.99(0.99-4.00)$ & 0.051 \\
\hline No & $336(89.4)$ & 72 (83.7) & 264 (91.1) & & \\
\hline Total & $376(100.0)$ & $86(100.0)$ & $290(100.0)$ & & \\
\hline \multicolumn{6}{|l|}{ Hospitalized ${ }^{4}$} \\
\hline Yes & $85(26.5)$ & $35(56.4)$ & 50 (19.3) & $5.42(3.00-9.77)$ & 0.000 \\
\hline No & $236(73.5)$ & 27 (43.6) & $209(80.7)$ & & \\
\hline Total & $321(100.0)$ & $62(100.0)$ & $259(100.0)$ & & \\
\hline \multicolumn{6}{|l|}{ Smoking } \\
\hline No & $276(73.4)$ & 225 (77.3) & $51(60.0)$ & $2.40(1.41-4.00)$ & 0.001 \\
\hline Yes & $100(26.6)$ & $66(22.7)$ & $34(40.0)$ & & \\
\hline Total & $376(100.0)$ & $291(100.0)$ & $85(100.0)$ & & \\
\hline \multicolumn{6}{|l|}{ Pathologic $R X^{5}$} \\
\hline a & $12(3.9)$ & 7 (10.6) & $5(2.0)$ & $5.55(1.75-20)$ & 0.001 \\
\hline Yes & $299(96.1)$ & $59(89.4)$ & $240(98.0)$ & & \\
\hline Total & $311(100.0)$ & $66(100.0)$ & $245(100.0)$ & & \\
\hline \multicolumn{6}{|l|}{ Cavitation } \\
\hline No & $128(48.9) 134$ & $29(74.4)$ & $99(44.4)$ & $3.70(1.69-7.69)$ & 0.001 \\
\hline Yes & (51.1) & $10(25.6)$ & $124(55.6)$ & & \\
\hline Total & $262(100.0)$ & $39(100.0)$ & $223(100.0)$ & & \\
\hline \multicolumn{6}{|l|}{ Extrapulmonary ${ }^{6} \mathrm{~TB}^{7}$} \\
\hline Yes & $109(29.1)$ & $36(42.4)$ & $73(25.3)$ & $2.17(1.31-3.60)$ & 0.002 \\
\hline No & 265 (70.9) & 49 (57.6) & $216(74.7)$ & & \\
\hline Total & $374(100.0)$ & $85(100.0)$ & $289(100.0)$ & & \\
\hline \multicolumn{6}{|l|}{ Pleural $^{8}$ TB $^{7}$} \\
\hline No & $50(47.2)$ & 27 (81.8) & $23(31.5)$ & $10.00(3.57-25.00)$ & 0.000 \\
\hline Yes & $56(52.8)$ & $6(18.2)$ & $50(68.5)$ & & \\
\hline Total & $106(100.0)$ & $35(100.0)$ & $73(100.0)$ & & \\
\hline \multicolumn{6}{|l|}{$\operatorname{SSM}(+)^{9}$} \\
\hline No & $117(35.8) 210$ & $49(71.0)$ & $68(26.4)$ & $6.67(3.85-12.5)$ & 0.000 \\
\hline Yes & (64.2) & $20(29.0)$ & $190(73.6)$ & & \\
\hline Total & $327(100.0)$ & $69(100.0)$ & $258(100.0)$ & & \\
\hline
\end{tabular}

${ }^{1}$ Values expressed as $\mathrm{n}(\%) ;{ }^{2}$ OR: Odds ratio; ${ }^{3} \mathrm{p}$ : $\mathrm{p}$ value; ${ }^{4}$ Hospitalized: patient who required hospitalization during treatment; ${ }^{5} \mathrm{Rx}$ : radiology; ${ }^{6}$ Extrapulmonary TB: includes exclusive extrapulmonary locations and mixed locations (pulmonary + extrapulmonary); ${ }^{7}$ TB: tuberculosis; ${ }^{8}$ Pleural TB: includes exclusive pleural locations and mixed locations (pleural + pulmonary); ${ }^{9}$ SSM (+): positive sputum smear microscopy 
Kirenga,et al., in Uganda, reported $26.3 \%$ of patients with a history of smoking; Cruz-Hervert, et al., in Vera Cruz (México) determined $25 \%$ of smokers, finding a statistically significant association between this addiction and ages $<45(5,19)$. These values are similar to the $26.9 \%$ found in Argentina, where there is no apparent association with age, but there is with regard to male gender. It is in this gender that, as documented, tobacco addiction prevails among the overall population $(12,20,21)$. These findings are relevant because a positive association between smoking and a lack of adherence to anti-tuberculosis treatment (22) has been highlighted.

The specific rate of HIV cases per 100,000 inhabitants in Argentina was 21.6 in 2011 (last year with complete information), totaling 18.8/100,000 inhabitants in 2013, but with incomplete notification (23). AIDS is another comorbidity associated with TB in this study's urban centers, occurring in $22.6 \%$ of TB patients. While associations between AIDS, male gender and age of $\geq 40$ years were observed, they were not statistically significant. Association with male gender could be related to an increase in the male/female ratio of HIV diagnoses in all regions in Argentina, and the connection with ages of $\geq 40$ years could reside in the fact that the median age of HIV diagnosis is 33 (23). Patients with AIDS are hospitalized almost five times more often than those without AIDS; they also have fewer pathological X-rays, less SSM positivity, and CD4+ T cell counts below $200 \mathrm{cells} / \mathrm{mm}^{3}$. Similar findings were also reported in a retrospective study conducted in Perú in 2016 (24). Only $18.2 \%$ of patients with TB/ HIV coinfection and extrapulmonary TB presented pleural forms; in those patients without co-infection, pleural TB accounted for $68.5 \%$ of cases.

An increased risk of TB infection, as well as that of TB disease among drug users, has been highlighted even before the emergence of HIV. Outbreaks of TB, both sensitive and drug-resistant, have also been described among drug users (25). According to previous studies, transmission of TB among cocaine users could be due to the presence of multiple risk factors in the places where they gather for consumption. In these patients the odds

Table 3. Comorbidities, other associated conditions, and demographic and clinical characteristics of tuberculosis adult patients in urban conglomerates of Argentina according age. August 2015-August 2016

\begin{tabular}{|c|c|c|c|c|c|c|}
\hline Characteristic & & Total $^{1}$ & $<40$ years & $\geq 40$ years & $\mathrm{OR}^{2}$ & $\mathbf{p}^{3}$ \\
\hline \multicolumn{7}{|l|}{ Drug addiction } \\
\hline & Yes & $55(14.7)$ & 38 (18.8) & $17(9.9)$ & $2.11(1.14-3.9)$ & 0.015 \\
\hline & No & 319 (85.3) & $164(81.2)$ & $155(90.1)$ & & \\
\hline & Total & $374(100.0)$ & $202(100.0)$ & $172(100.0)$ & & \\
\hline \multicolumn{7}{|l|}{ Alcoholism } \\
\hline & Yes & $38(10.2)$ & $13(6.4)$ & $25(14.5)$ & $0.40(0.20-0.82)$ & 0.010 \\
\hline & No & $336(89.8)$ & $189(93.6)$ & $147(85.5)$ & & \\
\hline & Total & $374(100.0)$ & $202(100.0)$ & $172(100.0)$ & & \\
\hline \multicolumn{7}{|l|}{ Hospitalized 4} \\
\hline & Yes & 84 (26.2) & 47 (25.8) & $37(26.8)$ & $0.95(0.57-1.57)$ & 0.843 \\
\hline & No & 236 (73.7) & 135 (74.2) & 101 (73.2) & & \\
\hline & Total & $320(100.0)$ & $182(100.0)$ & $138(100.0)$ & & \\
\hline \multicolumn{7}{|l|}{ Smoking } \\
\hline & Yes & 99 (26.5) & $50(24.7)$ & $49(28.5)$ & $0.83(0.52-1.31)$ & 0.415 \\
\hline & No & 275 (73.5) & $152(75.3)$ & $123(71.5)$ & & \\
\hline & Total & $374(100.0)$ & $202(100.0)$ & $172(100.0)$ & & \\
\hline \multicolumn{7}{|l|}{ Low weight } \\
\hline & Yes & $50(24.4)$ & 37 (31.9) & $13(14.6)$ & $2.74(1.35-5.55)$ & 0.004 \\
\hline & No & 155 (75.6) & 79 (68.1) & 76 (85.4) & & \\
\hline & Total & $205(100.0)$ & $116(100.0)$ & $89(100.0)$ & & \\
\hline \multicolumn{7}{|l|}{ Diabetes } \\
\hline & Yes & $47(12.6)$ & $11(5.5)$ & 36 (20.9) & $0.22(0.11-0.44)$ & 0.000 \\
\hline & No & 327 (87.4) & $191(94.5)$ & $136(79.1)$ & & \\
\hline & Total & $374(100.0)$ & $202(100.0)$ & $172(100.0)$ & & \\
\hline \multicolumn{7}{|l|}{$\mathrm{COPD}^{5}$} \\
\hline & Yes & $11(2.9)$ & $2(1.0)$ & $9(5.3)$ & $0.18(0.04-0.84)$ & 0.027 \\
\hline & No & $362(97.1)$ & $200(99.0)$ & $162(94.7)$ & & \\
\hline & Total & $373(100.0)$ & $202(100.0)$ & $171(100.0)$ & & \\
\hline
\end{tabular}

${ }^{1}$ Values expressed as $\mathrm{n}(\%) ;{ }^{2}$ OR: Odds ratio; ${ }^{3} \mathrm{p}$ : $\mathrm{p}$ value; ${ }^{4} \mathrm{Hospitalized:} \mathrm{patient} \mathrm{who} \mathrm{required} \mathrm{hospitalization} \mathrm{during} \mathrm{treatment;}{ }^{5} \mathrm{COPD}:$ Chronic Obstructive Pulmonary Disease 
of treatment default are higher, remaining infectious for extended periods after diagnosis and developing drug resistant TB (26). In this study, drug use was one of the most common conditions $(14.6 \%)$, and it was related to male gender, the presence of AIDS, and ages under 40 among TB patients. On this basis, strategies can be designed which adapt to these circumstances, thus reducing its negative outcomes.

Low weight is another common feature among TB patients, occurring in $24.3 \%$ of them and rising to $31.9 \%$ in patients $<40$ years of age. Other authors have found a mean BMI of 21.1 , very similar to that in Argentina, which did not decrease significantly in the presence of comorbidities (4). In Córdoba, Argentina, $63 \%$ of patients had a $\mathrm{BMl}<21.63$, very similar to that of this study where the median was 21.22 (14). Zachariah, et al. found that patients with a $\mathrm{BMI}<17$ had a higher risk of dying than those with a BMl $\geq 18.5$ (27); in that case, $12.2 \%$ of patients in Argentina would be at increased risk of dying because of their low weight. Another study found that overweight was not associated with the risk of dying during TB treatment; however, low weight was (28). In this respect, in urban centers from Argentina, $24.3 \%$ of patients being treated for TB had a higher risk of dying.

In a systematic review of TB research, diabetes mellitus appears to increase about threefold the risk of developing TB disease (29). Patients with TB and diabetes mellitus have also a higher baseline bacterial burden, longer bacteriological conversion time during treatment, higher risk of having multidrug resistance, treatment failure, and recurrence and death, compared to patients without diabetes mellitus $(30,31)$. In Argentina 4 out of 10 adult people were overweight and 2 out of 10 were obese; 1 out of $10(9.8 \%$ of the total population aged $\geq 18)$ had diabetes mellitus, according to data from the Third National Risk Factor Survey conducted in 2013 (32). This prevalence of diabetes mellitus is consistent with the $12.5 \%$ by TB patients in this study. The association between diabetes mellitus and overweight or obesity and age of $\geq 40$ suggests it is necessary to carry out a comprehensive TB and diabetes mellitus approach, focusing this issue on patients $>40$ who are overweight or obese.

One study limitation was illegibility or incomplete information in medical records available in health services. So was staff turnover in hospitals, which meant that the person to enter the patient was not aware of the information to be collected at the time or the importance of requesting HIV testing.
Another limitation is that at the time the study analysis was conducted, many patients were still under treatment, so it was not possible to know their outcome.

This study not only helps recognize the characteristics and comorbidities of TB patients influencing TB development and evolution, for their approach within clinics, it also characterizes them by age and gender, thus facilitating inter-sector approaches to cover social and community aspects. This type of study and its approach strategy should be implemented by NTPs to help reduce the scourge of TB.

\section{Acknowledgements}

We thank pneumonology specialists Rosana Billone, Cristina Chirico, Marcela Fraga, Cristina Gaitán, Leticia Limongi, Eduardo Maniago, Cristian Muller, María Elisabet Pizarro, Alejandra Poropat, César Salomone, Ana Putruelle, Susana Tanco, and the Graduate in Social Work Leandro Iparraguirre, for the collection of information from patients in their respective services.

\section{Conflicts of interest}

The authors declare they have no conflicts of interest regarding the content of this article.

\section{Funding}

Authors did not receive any external funding.

\section{References}

1. World Health Organiation. Global tuberculosis report 2016. Geneva: WHO; 2016. Accessed: May $3^{\text {rd }}$, 2017. Available in: http://reliefweb.int/sites/reliefweb.int/files/resources/ gtbr2016_main_text.pdf

2. Instituto Nacional de Enfermedades Respiratorias "Dr. Emilio Coni". Notificación de casos de tuberculosis en la República Argentina, período 1980-2015. Santa Fe: INER; 2016. Accessed: May $3^{\text {rd }}$, 2017. Available in: http://www. anlis.gov.ar/iner/wp-content/uploads/2016/11/Notificacionde-casos-de-Tuberculosis-en-la-Republica-ArgentinaPeriodo-1980-2015.pdf

3. Caminero J. Guía de la tuberculosis para médicos especialistas. Paris: UICTER; 2003. Accessed: May $3^{\text {rd }}$, 2017]. Available in: http://www.theunion.org/what-wedo/publications/technical/spanish/pub_guia_medicos_ especialistas_spa.pdf

4. Kim SY, Lee SM, Yim JJ, Yoo CG, Kim YW, Han SK, et al. Treatment response and adverse reactions in older tuberculosis patients with immunocompromising comorbidities. Yonsei Med J. 2013;54:1227-33. https://doi. org/10.3349/ymj.2013.54.5.1227

5. Kirenga BJ, Ssengooba W, Muwonge C, Nakiyingi $\mathrm{L}$, Kyaligonza S, Kasozi S, et al.Tuberculosis risk factors among tuberculosis patients in Kampala, Uganda: Implications for tuberculosis control. BMC Public Health. 2015;15:13. https://doi.org/10.1186/s12889-015-1376-3 
6. Wang JY, Lee LN, Hsueh PR. Factors changing the manifestation of pulmonary tuberculosis. Int J Tuberc Lung Dis. 2005;9:777-83.

7. El Sahly HM, Wright JA, Soini H, Bui TT, Williams-Bouyer $\mathbf{N}$, Escalante P, et al. Recurrent tuberculosis in Houston, Texas: A population-based study. Int $\mathrm{J}$ Tuberc Lung Dis. 2004;8:333-40.

8. Yen YF, Yen MY, Lin YS, Lin YP, Shih HC, Li LH, et al. Smoking increases risk of recurrence after successful antituberculosis treatment: A population-based study. Int $\mathrm{J}$ Tuberc Lung Dis. 2014;18:492-8. https://doi.org/10.5588/ ijtld.13.0694

9. Yüceege M, Sanisoğlu B, Baran R. Gender difference in clinical presentation of Turkish patients with pulmonary tuberculosis. Acta Medica Iranica. 2014;52:52-5.

10. Díaz-Mesa E, García-Portilla P, Fernández-Artamendi S, Sáiz P, BobesBascarán T, Casares MJ, et al. Diferencias de género en la gravedad de la adicción. Adicciones. 2016;28:221-30.

11. Bottorff J, Haines-Saah R, Kelly M, Oliffe J, Torchalla I, Poole N, et al. Gender, smoking and tobacco reduction and cessation: A scoping review. Int $\mathrm{J}$ Equity in Health. 2014;13:114. https://doi.org/10.1186/s12939-014-0114-2

12. Minutillo A, Pacifici R, Scaravelli G, De Luca R, Palmi I, Mortali C, et al. Gender disparity in addiction: An Italian epidemiological sketch. Ann Ist Super Sanità. 2016;52:17683. https://doi.org/10.4415/ANN_16_02_08

13. Fescina P, Membriani E, Limongi L, Putruele A. Incidencia de la resistencia a drogas en tuberculosis y su asociación a comorbilidades en pacientes tratados en un hospital universitario. Rev Am Med Resp. 2013;2:64-70.

14. Rivera L, VarujanKevorkof G, Oviedo E, Acosta MA, Najo M, Granados M, et al. Características epidemiológicas de pacientes con tuberculosis en el Hospital Tránsito Cáceres de Allende. Rev Am Med Resp. 2014;14:404-11.

15. Organización Panamericana de la Salud. Marco de trabajo para el control de la tuberculosis en grandes ciudades de Latinoamérica y el Caribe. Washington, D.C.: OPS; 2016. Accessed: May 3 $3^{\text {rd }}$, 2017. Available in: http:// www.paho.org/hq/index.php?option=com_topics\&view=arti cle\&id=59\&ltemid $=40776$ \&lang $=e s$

16. Marais B, Lönnroth K, Lawn S, Migliori G, Mwaba $\mathbf{P}$, Glaziou $\mathbf{P}$ et al. Tuberculosis comorbidity with communicable and non-communicable diseases: Integrating health services and control efforts. Lancet Infect Dis. 2013;13:436448. https://doi.org/10.1016/S1473-3099(13)70015-X

17. World Health Organization/The Union. TB and tobacco control: Joining efforts to control two related global epidemics. Geneva: WHO, 2007. Accessed: May 3rd 2017. Available in: http://apps.who.int/iris/bitstream/10665/43812/ 1/9789241596220_eng.pdf

18. Hassmiller KM. The association between smoking and tuberculosis. Salud Pública Mex. 2006;48:S201-16. https:// doi.org/10.1590/S0036-36342006000700024

19. Cruz-Hervert L, García-García L, Ferreyra-Reyes L, Bobadilla-Del Valle M, Cano-Arellano B, CanizalesQuintero S, et al. Tuberculosis in ageing: High rates, complex diagnosis and poor clinical outcomes. Age Ageing. 2012;41:488-95. https://doi.org/10.1093/ageing/afs028
20. Mahfouz M, Alsanosy R, Gaffar A, Makeen A. Tobacco use among university students of Jazan region: Gender differences and associated factors. Biomed Res Int. 2014; 2014:279231. https://doi.org/10.1155/2014/279231

21. Ministerio de Salud de Argentina. Encuesta Mundial de tabaquismo en adultos 2012. Buenos Aires: 2013. Accessed: May $3^{\text {rd }}$, 2017. Available in: http://www.msal.gob. ar/tabaco/images/stories/info-para-ciudadanos/pdf/201307_GYTS-2012-resumen-ejecutivo.pdf

22. Underner M, Perriot J, Peiffer G, Meurice JC, Dautzenberg B. Smoking and adherence to anti-tuberculosis treatment. Rev Mal Respir. 2016;33:128-44. Accessed: August 25th, 2017. Available in: http://www.em-consulte.com/rmr/article/ 1037819/

23. Ministerio de Salud de Argentina. Boletín sobre el VIHsida e ITS en Argentina. Buenos Aires, 2015. Accessed: $3^{\text {rd }}$ May 2017. Available in: http://www.msal.gob.ar/images/ stories/bes/graficos/0000000852cnt-2015-11-18_boletinvih-sida-2015.pdf

24. Velásquez G, Cegielski J, Murray M, Yagui M, Asencios L, Bayona J, et al. Impact of HIV on mortality among patients treated for tuberculosis in Lima, Perú: A prospective cohort study. BMC Infect Dis. 2016;16:45. https://doi.org/10.1186/ s12879-016-1375-8

25. Deiss RG, Rodwell TC, Garfein RS. Tuberculosis and illicit drug use: Review and update. Clin Infect Dis. 2009;48:7282. https://doi.org/10.1086/594126

26. Story A, Bothamley G, Hayward A. Crack cocaine and infectious tuberculosis. Emerg Infect Dis. 2008;14:1466-9. https://doi.org/10.3201/eid1409.070654

27. Zachariah R, Spielmann MP, Harries AD, Salaniponi FM. Moderate to severe malnutrition in patients with tuberculosis is a risk factor associated with early death. Trans $R$ Soc Trop Med Hyg. 2002;96:291-4.

28. Yen YF, Chuang PH, Yen MY, Lin SY, Chuang P, Yuan MJ, et al. Association of body mass index with tuberculosis mortality a population-based follow-up study. Medicine (Baltimore). 2016;95:e2300. https://doi.org/10.1097/MD. 0000000000002300

29. Jeon CY, Murray MB. Diabetes mellitus increases the risk of active tuberculosis: A systematic review of 13 observational studies. PLoS Med. 2008;5:e152. https://doi.org/10.1371/ journal.pmed.0050152

30. Zahr R, Peterson R, Polgreen L, Cavanaugh J, Hornick D, Winthrop K, et al. Diabetes as an increasingly common comorbidity among patient hospitalizations for tuberculosis in the USA. BMJ Open Diabetes Res Care. 2016;4:e000268. http://dx.doi.org/10.1136/bmjdrc-2016-000268

31. Pal R, Ansari M, Hameed S, Fatima Z. Diabetes mellitus as hub for tuberculosis infection: A snapshot. Int J Chronic Dis. 2016;2016:5981574. https://doi.org/10.1155/2016/5981574

32. Ministerio de Salud, Instituto Nacional de Estadísticas y Censos de Argentina. Tercera Encuesta Nacional de Factores de Riesgo para Enfermedades No transmisibles, Argentina 2013. Buenos Aires, 2015. Accessed: May 3rd, 2017. Available in: http://www.msal.gob.ar/images/stories/ bes/graficos/0000000544cnt-2015_09_04_encuesta_ nacional_factores_riesgo.pdf 